\title{
Physiologic Dead Space Assessment: Field of Dreams or Clinical Paradigm?
}

In this issue of Respiratory CARE, Siobal and colleagues report on the correlation, precision, and bias of calculated physiologic dead space, determined using the volumetric capnography module available in the Dräger XL ventilator, compared to other methods (metabolic analyzer and volumetric $\mathrm{CO}_{2}$ monitor). ${ }^{1}$ It is important to note that the investigators choose comparative technologies that reflect the standard of care for monitoring the ratio of dead space to tidal volume $\left(\mathrm{V}_{\mathrm{D}} / \mathrm{V}_{\mathrm{T}}\right)$ at many institutions. Volumetric capnography is a relatively new addition to mechanical ventilators. Through their investigation, Siobal and colleagues demonstrate a high degree of association between the $\mathrm{V}_{\mathrm{D}} / \mathrm{V}_{\mathrm{T}}$ derived through the Dräger ventilator module (using volumetric capnography) and other comparative technologies (Deltatrac, Metascope, Vmax Encore, and $\mathrm{NICO}_{2}$ ).

See the Original Study on Page 1143

In a comparison of 67 measurements obtained from 36 mechanically ventilated adult patients, all of whom were recovering from acute lung injury or ARDS, the overall correlation between the Dräger derived $\mathrm{V}_{\mathrm{D}} / \mathrm{V}_{\mathrm{T}}$ and that of the metabolic analyzers was $r=0.96$, with a bias of -0.19 and precision of \pm 0.03 . The authors appropriately conclude from their study that the Dräger XL's volumetric capnography measurements can accurately calculate $\mathrm{V}_{\mathrm{D}} / \mathrm{V}_{\mathrm{T}}$ without the use of a metabolic analyzer or volumetric $\mathrm{CO}_{2}$ monitor. This study demonstrates that the volumetric $\mathrm{CO}_{2}$ module incorporated into the Dräger XL ventilator can be employed to determine physiologic dead space. However, the question still needs to be answered: Should we monitor physiologic dead space in our ventilated patient population? In other words, what evidence supports the use of $\mathrm{V}_{\mathrm{D}} / \mathrm{V}_{\mathrm{T}}$ as a monitor of ventilator efficiency?

As Siobal and colleagues point out, dead-space ventilation was first described by Bohr in $1891,{ }^{2}$ and subsequently modified by Enghoff in $1938 .^{3}$ For over 100 years, researchers and clinicians have been aware of the concept of $\mathrm{V}_{\mathrm{D}} / \mathrm{V}_{\mathrm{T}}$. Initially, the required technology was limited and cumbersome, making clinical utilization of $\mathrm{V}_{\mathrm{D}} / \mathrm{V}_{\mathrm{T}}$ impractical. Within the last 4 decades, advances in mechanical ventilation and expiratory gas analysis have aided efforts to investigate $V_{D} / V_{T}$ as a marker of lung function in a variety of patient conditions and populations. ${ }^{4-14}$ The most recent technological advances have included the incorporation of volumetric capnography as a mechanical ventilator module. ${ }^{15,16}$ These advances allow for continuous assessment of carbon dioxide production $\left(\dot{\mathrm{V}}_{\mathrm{CO}_{2}}\right)$ and the mixed exhaled pressure of carbon dioxide $\left(\mathrm{P}_{\mathrm{ECO}_{2}}\right)$. The addition of the ventilator module should allow practitioners to advance our questions pertaining to the utility of $\mathrm{V}_{\mathrm{D}} / \mathrm{V}_{\mathrm{T}}$ in ventilator management of our patients.

It is clear that our profession and the medical field in general have provided adequate verification that current technology for measurement of $\mathrm{V}_{\mathrm{D}} / \mathrm{V}_{\mathrm{T}}$ provides comparable results, when compared to prior technological standards. The work of Siobal and colleagues ${ }^{1}$ serves to advance our confirmation that the newest addition to $\mathrm{V}_{\mathrm{D}} / \mathrm{V}_{\mathrm{T}}$ monitoring, specifically volumetric capnography employed by the Dräger $\mathrm{XL}$, is a viable alternative to $\mathrm{V}_{\mathrm{D}} / \mathrm{V}_{\mathrm{T}}$ estimation via other means. The real challenge for us as respiratory care practitioners is to apply our knowledge to assess the clinical utility of this measurement in ventilator management. At present, the body of knowledge that describes the relationship between changing pulmonary function, ventilator support, and $\mathrm{V}_{\mathrm{D}} / \mathrm{V}_{\mathrm{T}}$ is inadequate to adopt $\mathrm{V}_{\mathrm{D}} / \mathrm{V}_{\mathrm{T}}$ as a standard of care. This fact is acknowledged by the authors in their conclusion.

If $\mathrm{V}_{\mathrm{D}} / \mathrm{V}_{\mathrm{T}}$ assessment demonstrates a strong association with pulmonary function modulation and ventilator manipulation, then we should adopt $\mathrm{V}_{\mathrm{D}} / \mathrm{V}_{\mathrm{T}}$ as a new paradigm in ventilator monitoring. On the other hand, if we fail to demonstrate such an association, then $\mathrm{V}_{\mathrm{D}} / \mathrm{V}_{\mathrm{T}}$ becomes just another "Field of Dreams" modality. The responsibility to define the practical uses for $\mathrm{V}_{\mathrm{D}} / \mathrm{V}_{\mathrm{T}}$ resides with us, the respiratory care practitioner, and our healthcare partners.

\author{
Ronald E Dechert DrPH MSc RRT FAARC \\ Pediatric Respiratory Care \\ CS Mott Children's Hospital \\ University of Michigan \\ Ann Arbor, Michigan
}

\section{REFERENCES}

1. Siobal MS, Ong H, Valdes J, Tang J. Calculation of physiologic dead space: comparison of ventilator volumetric capnography to measure- 


\section{Physiologic Dead Space Assessment: Field of Dreams or Clinical Paradigm?}

ments by metabolic analyzer and volumetric $\mathrm{CO}_{2}$ monitor. Respir Care 2013;58(7):1143-1151.

2. Bohr C. Über die Lungeatmung. Skand Arch Physiol 1891;2:236238. Article in German.

3. Enghoff $\mathrm{H}$. Volumen inefficax: bemerkungen zur frage des schadlichen raumes. Upsala Lakareforen Forh 1938;44:191-218. Article in German.

4. Smith ER. Measurement of physiologic deadspace during mechanical ventilation. Respir Care 1977;22(12):1341-1342.

5. Burki NK. The deadspace to tidal volume ratio in the diagnosis of pulmonary embolism. Am Rev Respir Dis 1986;133(4):679-685.

6. Gattinoni L, Bombino M, Pelosi P, Lissoni A, Pesenti A, et al. Lung structure and function in different stages of severe adult respiratory distress syndrome. JAMA 1994;271(22):1772-1779.

7. Bein T, Reber A, Stjernström H, Metz C, Taeger K, Hedenstierna G. [Ventilation-perfusion ratio in patients with acute respiratory insufficiency]. Anaesthesist 1996;45(4):337-342. Article in German.

8. Hubble CL, Gentile MA, Tripp DS, Craig DM, Meliones JN, Cheifetz IM. Deadspace to tidal volume ratio predicts successful

The author has disclosed no conflicts of interest.

Correspondence: Ronald E Dechert DrPH MSc RRT FAARC, Pediatric Respiratory Care, CS Mott Hospital, University of Michigan, 200 E Hospital Drive, F5815, Ann Arbor MI 48109. E-mail: rdechert@umich.edu.

DOI: $10.4187 /$ respcare.02561 extubation in infants and children. Crit Care Med 2000;28(6):20342040.

9. Nuckton TJ, Alonso JA, Kallet RH, Daniel BM, Pittet JF, Eisner MD, Matthay MA. Pulmonary dead-space fraction as a risk factor for death in the acute respiratory distress syndrome. N Engl J Med 2002;346(17):1281-1286.

10. Beydon L, Uttman L, Rawal R, Jonson B. Effects of positive endexpiratory pressure on deadspace and its partitions in acute lung injury. Intensive Care Med 2002;28(9):1239-1245.

11. Kallet RH, Alonso JA, Pittet JF, Matthay MA. Prognostic value of the pulmonary dead-space fraction during the first 6 days of acute respiratory distress syndrome. Respir Care 2004;49(9):1008-1014.

12. Lucangelo U, Bernabè F, Vatua S, Degrassi G, Villagrà, Fernandez $\mathrm{R}$, Romero PV, et al. Prognostic value of different deadspace indices in mechanically ventilated patients with acute lung injury and ARDS. Chest 2008;133(1):62-71.

13. Kallet RH, Siobal MS. Measuring deadspace: does it really matter? Or, what are we waiting for? Respir Care 2010;55(3):350-352.

14. Raurich JM, Vilar M, Colomar A, Ibáñez J, Ayestarán I, PérézBárcena J, Llompart-Pou JA Prognostic value of the pulmonary deadspace fraction during the early and immediate phases of acute respiratory distress syndrome. Respir Care 2010;55(3):282-287.

15. Hedenstierna G, Sandhagen B. Assessing dead space: a meaningful variable? Minerva Anestesiol 2006;72(6):521-528.

16. Tusman G, Sipmann FS, Bohm SH. Rationale of deadspace measurement by volumetric capnography. Anesth Analg 2012;114(4): 866-874. 